THE BEDFORD SERIES IN HISTORY AND CULTURE

\title{
Christopher Columbus and the Enterprise of the Indies
}

A Brief History with Documents

\section{Geoffrey Symcox}

and

Blair Sullivan

\author{
palgrave
}




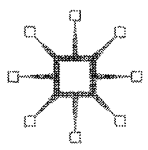

CHRISTOPHER COLUMBUS AND THE ENTERPRISE

OF THE INDIES by Geoffrey Symcox and Blair Sullivan

The Library of Congress has catalogued the paperback edition as follows: 2004107918

Copyright (C) 2005 by Bedford/St. Martin's

Softcover reprint of the hardcover 1st edition 2005 978-1-4039-6807-4

All rights reserved. No part of this book may be used or reproduced in any manner whatsoever without written permission except in the case of brief quotations embodied in critical articles or reviews.

First published 2005 by

PALGRAVE MACMILLAN ${ }^{\mathrm{TM}}$

175 Fifth Avenue, New York, N.Y. and

Houndmills, Basingstoke, Hampshire, England RG21 6XS.

Companies and representatives throughout the world.

PALGRAVE MACMILLAN is the global academic imprint of the Palgrave Macmillan division of St. Martin's Press, LLC and of Palgrave Macmillan Ltd. Macmillan ${ }^{\circledR}$ is a registered trademark in the United States, United Kingdom and other countries. Palgrave is a registered trademark in the European Union and other countries.

ISBN 978-1-349-73437-5 ISBN 978-1-137-08059-2 (eBook)

DOI 10.1007/978-1-137-08059-2

A catalogue record for this book is available from the British Library.

First edition: October 2004

10987654321

\section{Acknowledgments}

Excerpts from volume 2 of the Repertorium Columbianum, courtesy of Professor Helen Nader, University of Arizona.

Excerpts from volume 3 of the Repertorium Columbianum, courtesy of the UCLA Center for Medieval and Renaissance Studies.

Excerpts from volumes 4 through 12 of the Repertorium Columbianum, courtesy of Brepols Publishers, Turnhout, Belgium.

Excerpts from Diego Alvarez Chanca, Medico di Cristoforo Colombo, courtesy of the Consiglio Nazionale delle Ricerche, Cagliari, Italy. 


\section{Foreword}

The Bedford Series in History and Culture is designed so that readers can study the past as historians do.

The historian's first task is finding the evidence. Documents, letters, memoirs, interviews, pictures, movies, novels, or poems can provide facts and clues. Then the historian questions and compares the sources. There is more to do than in a courtroom, for hearsay evidence is welcome, and the historian is usually looking for answers beyond act and motive. Different views of an event may be as important as a single verdict. How a story is told may yield as much information as what it says.

Along the way the historian seeks help from other historians and perhaps from specialists in other disciplines. Finally, it is time to write, to decide on an interpretation and how to arrange the evidence for readers.

Each book in this series contains an important historical document or group of documents, each document a witness from the past and open to interpretation in different ways. The documents are combined with some element of historical narrative - an introduction or a biographical essay, for example - that provides students with an analysis of the primary source material and important background information about the world in which it was produced.

Each book in the series focuses on a specific topic within a specific historical period. Each provides a basis for lively thought and discussion about several aspects of the topic and the historian's role. Each is short enough (and inexpensive enough) to be a reasonable one-week assignment in a college course. Whether as classroom or personal reading, each book in the series provides firsthand experience of the challengeand fun - of discovering, recreating, and interpreting the past.

Natalie Zemon Davis

Ernest R. May

Lynn Hunt

David W. Blight 



\section{Preface}

Columbus is a historical figure of incontrovertible importance. He was long hailed as the "discoverer" who brought Christianity and European civilization to the American continent. But political and cultural developments, particularly the breakup of European colonial empires after World War II, led scholars to raise serious questions about Columbus's motives and methods, and about the impact of Spanish colonization on the indigenous peoples of the Americas. Although they still recognize the unparalleled historical significance of his voyages, and pay tribute to the courage and technical skill that made them possible, most scholars today have adopted a more critical stance toward Columbus and what he did. As editors of the Repertorium Columbianum, a multivolume collection of contemporary sources bearing on Columbus's voyages, we have set out to convey to a nonspecialist audience some of the results of the current scholarly debates and recent research on Columbus and his voyages.

The introduction to this volume provides a narrative of Columbus's extraordinary career. Born to a humble family in the great mercantile city of Genoa, Columbus went to sea at an early age. A decade of residence in Portugal perfected his seafaring skills and planted the seed of his plan to sail west in search of a shortcut to the fabled wealth of Asia. In 1492, as every schoolchild knows, he secured support from the Spanish monarchs for his venture, sailed across the Atlantic, and reached a group of islands, which he claimed for the Spanish crown. Believing he had reached the eastern coast of Asia, he mistakenly named them the "Indies," and their inhabitants "Indians."

Columbus's voyage marked the beginning of what would come to be called Spain's "Enterprise of the Indies" - the colonization and evangelization of the new lands. In 1493 the Spanish crown sent Columbus on a second voyage to establish a permanent settlement in the Indies. But the new colony was soon beset by dire problems: disease, famine, 
strife among the settlers, and warfare against the indigenous population. For the inhabitants of the Indies, the arrival of the Europeans was catastrophic. It disrupted their traditional way of life and condemned them to extinction within a few decades. Columbus did nothing to prevent the colonists' brutal exploitation of the indigenous population; in fact, he actively participated in it. Meanwhile he embarked on another voyage of exploration in 1498 and became the first European to reach the South American continent, giving further proof of his brilliance as a navigator. But as a colonial governor he proved a failure, and the Spanish monarchs recalled him in disgrace in 1500. They still prized his nautical skills, however, and sent him on another voyage of exploration in $1502-4$, in the course of which he reached the coast of Central America. Columbus died in 1506, bequeathing to his sons the titles and the wealth he had accumulated as the reward for his exploits.

The introduction concludes by examining the controversies that have grown up around Columbus and the impact of his voyages, tracing how his reputation has waxed and waned, especially in the United States. The introduction also includes a table listing the main crops, animals, and diseases that were exchanged among Eurasia, Africa, and the Americas after 1492 in the so-called Columbian Exchange. This was perhaps the most important-although unintended-consequence of the contact that Columbus initiated between what Europeans soon came to call the "Old World" and the "New." In addition, the introduction includes a genealogical table of the Columbus family and several maps depicting the voyages Columbus undertook. ${ }^{1}$

Following the introduction is a series of contemporary documents that describe Columbus and his four voyages. These documents include excerpts from the $\log$ of his first voyage and a wide variety of other materials: official documents like legal records relating to his family's activity in Genoa, his agreements with the Spanish crown, and papal bulls demarcating the nascent colonial empires of Spain and Portugal; accounts of Columbus's three later voyages, some by eyewitnesses; the first European descriptions of the Indies, of their flora and fauna, of their inhabitants and their culture; and judgments by contemporaries of Columbus and his achievements.

A vast range of materials has been unearthed and analyzed since serious scholarly research on Columbus and his voyages began two

${ }^{1}$ Place names appear in Spanish where applicable, for consistency with the names used in the documents. 
centuries ago. We have selected the sources included here to give an idea of the wealth of documentation that exists for studying the man and his career. To make the documents easily intelligible, we provide short commentaries that situate them in their context and gloss notes that explain any obscure terms they may contain. Our aim is to present a balanced view of Columbus and his achievements. We hope our readers will evaluate these documents for themselves and come to their own conclusions about the nature, purpose, and impact of Columbus's voyages, always remembering that research continues, that interpretations constantly change, and that there are no final, definitive answers to the questions the documents raise. Concluding this volume are a chronology to help readers follow Columbus's life and his four voyages, a glossary of terms, a list of questions for further consideration, and a selected bibliography of primary and secondary sources related to Columbus.

\section{ACKNOWLEDGMENTS}

We must record several debts of gratitude to those who have helped us in writing this book. First, to the press for their careful editorial work on the manuscript, and especially to Carina Schoenberger, developmental editor, and Emily Berleth, production manager. Second, to the eight outside reviewers who offered many helpful criticisms and suggestions for improving it: James Axtell, College of William and Mary; Paul Cullity, Keene State College; Paul W. Mapp, College of William and Mary; Helen Nader, University of Arizona; Anthony Pagden, University of California, Los Angeles; William D. Phillips Jr., University of Minnesota; Jim Ross-Nazzal, Montgomery College; and Roger Schlesinger, Washington State University. Finally, to the members of Geoffrey Symcox's undergraduate seminar on Columbus in Winter Term 2004 at UCLA, who read the manuscript and offered many useful criticisms of it from the viewpoint of the student audience for whom it is intended. To all of them, our sincere thanks.

Geoffrey Symcox Blair Sullivan 



\section{Contents}

Foreword iii

Preface v

LIST OF MAPS AND ILLUSTRATIONS xiii

\section{PART ONE}

Introduction: Columbus - The Man, the Voyages, the Legacy

Columbus's Genoese Origins and Early Life 3

Columbus in Portugal, 1476-1485

Columbus in Spain, 1485-1492 11

The First Voyage, 1492-1493 14

The Second Voyage, 1493-1496: Colonization 18

The Third Voyage, 1498-1500 23

The Fourth Voyage, 1502-1504, and Columbus's Last Years 26

Columbus's Legacy $\quad 30$

Columbus after Columbus $\quad 34$ 


\section{PART TWO}

\section{Christopher Columbus}

1. Agreement Mentioning Domenico Colombo and His Son Christopher Columbus, Genoa, September 22, 1470

2. Notarial Document Mentioning Christopher Columbus's Trip to Madeira to Purchase Sugar, Genoa, August 25, 1479

3. Bartolomé de Las Casas, On Columbus's Appearance, Education, and Character, ca. 1527-1563

4. Gonzalo Fernández de Oviedo, On Columbus's Appearance and Origins, 1535-ca. 1549

5. Christopher Columbus, Undated Letter to Fernando and Isabel, 1500-1502

6. Christopher Columbus, Letter to Nicolò Oderigo, with "X $\rho$ o ferens" Signature, March 21, 1502

7. Bartolomé de Las Casas, On Columbus as an Instrument of God's Will, ca. 1527-1563

8. Gonzalo Fernández de Oviedo, On Columbus as "First Discoverer," 1535-ca. 1549

9. Agostino Giustiniani, Psalter, On Columbus the Evangelist, 1516

\section{The Four Voyages}

First Voyage, 1492-1493

10. Santa Fe Capitulations, Santa Fe, April 17, 1492

11. Granada Capitulations, Granada, April 30, 1492

12. Christopher Columbus, Selected Entries from the Log, August 3, 1492-March 15, 1493

13. Warrant to Christopher Columbus and Juan Rodriguez de Fonseca Commissioning Them to Outfit the Second Voyage, Barcelona, May 24, 1493 
14. Michele da Cuneo, From News of the Islands of the Hesperian Ocean Discovered by Sir Christopher Columbus of Genoa, October 1495

15. Giambattista Strozzi, Letter from Cádiz, March 19, 1494

16. Giovanni de' Bardi, Letter from Seville, April 19, 1494

Third Voyage, 1498-1500

17. Instructions to Columbus for Colonization of the Indies, Burgos, April 23, 1497

18. Bartolomé de Las Casas, On Columbus's Third Voyage, ca. 1527-1563

19. Andrés del Corral, Testimony concerning Columbus's Landing on the South American Mainland, Santo Domingo, June 16, 1512

20. Christopher Columbus, Letter to Juana de la Torre, Making the Case for the Restitution of His Privileges, Late 1500

Fourth Voyage, 1502-1504

21. Writ Ordering Restitution of Property to the Admiral and His Brothers, Granada, September 27, 1501

22. Bartolomé de Las Casas, On Columbus's Fourth Voyage, ca. 1527-1563

\section{The Spanish Crown, Portugal, and the} Papacy

23. Alexander VI, Papal Bull "Inter Cetera II," Rome, May 4, 1493

24. Alexander VI, Papal Bull "Piis Fidelium," Rome, June 25, 1493

25. Alexander VI, Papal Bull "Dudum Siquidem," Rome, September 25, 1493

26. Treaty of Tordesillas between Spain and Portugal, June 7, 1494 
27. Alexander VI, Papal Bull "Eximie Devotionis," Rome, November 16, 1501

4. European Constructions of the New World

155

28. Allegretto Allegretti, Sienese Diaries from 1450 to 1496, April 25, 1493

29. Morelletto Ponzone, Letter from Ferrara, June 11, 1494

30. Diego Alvarez Chanca, From His Report to the City Council of Seville on Columbus's Second Voyage, ca. 1494

31. Ramón Pané, On Taino Religious Practices, ca. 1498

32. Peter Martyr of Anghiera, On Tainos, Caribs, the Flora and Fauna of the Indies, and the Golden Age of Life According to Nature, 1511

33. Alessandro Geraldini, On Caribs and Tainos, March 29, 1522

\section{APPENDIXES}

A Christopher Columbus Chronology (1451-1506) 177

Glossary 180

Questions for Consideration 182

Selected Bibliography 184

\section{Index 187}




\section{Maps and Illustrations}

MAPS

1. The Voyages of Columbus 38

2. The Caribbean Region $\quad 39$

3. Northern South America 40

ILLUSTRATIONS

1. Columbus's Family Tree 4

2. View of Late Fifteenth-Century Genoa 6

3. Ptolemaic Map of the World 10

4. The Columbian Exchange 32

5. The Indians of Guanahaní Greet Columbus 69

6. A Zemi, a Taino Deity Figure 161

7. Cannibals of the West Indies 168 